\title{
NON-ALCOHOLIC FATTY LIVER DISEASE IN DIABETIC PATIENTS AS RISK FACTOR FOR POOR PROGNOSIS OF COVID-19: AN UPDATE OF POTENTIAL MECHANISMS AND TREATMENT CONSIDERATIONS
}

\author{
OVIDIU PAUL CALAPOD, ANDREEA MARIA MARIN, LAURA CARINA TRIBUS *, CARMEN \\ FIERBINŢEANU-BRATICEVICI
}

\author{
Gastroenterology Department, Bucharest Emergency University Hospital, “Carol Davila” University of Medicine and \\ Pharmacy, Bucharest, Romania
}

*corresponding author: ltribusro@yahoo.com

Manuscript received: July 2020

\begin{abstract}
In the global context of COVID-19 outbreak, scientific efforts have been directed to investigate the risk factors associated with the development of severe illness. Emerging evidence linked the metabolic syndrome to more severe forms of the disease. The majority of the patients with these risk factors develop hepatic injury, particularly those previously diagnosed with nonalcoholic fatty liver disease (NAFLD). NAFLD is the most common cause of chronic liver disease, affecting a quarter of the population worldwide. While type II diabetes mellitus is linked to a higher severity of COVID-19, it has not been established whether patients with metabolic-associated fatty liver disease are prone to worse outcomes. To have a closer look at the consequences of this association, we have systematically searched the latest updates and studies to assess the connection between NAFLD and the severity of COVID-19, as well as the treatment considerations.
\end{abstract}

\section{Rezumat}

În contextul pandemiei COVID-19, eforturile cercetătorilor au fost îndreptate spre a identifica factorii de risc asociați cu progresia severă a bolii. Studii recente scot în evidență legătura sindromului metabolic cu formele grave de COVID-19. O proporție mare din pacienții cu tulburări metabolice au dezvoltat afectare hepatică, în special cei diagnosticați anterior cu boala ficatului gras non-alcoolic (FGNA), patologie ce afectează peste un sfert din populația lumii. În timp ce diabetul zaharat tip II este cunoscut ca fiind factor de risc pentru evoluția severă a COVID-19, nu este încă stabilit dacă pacienții cu FGNA asociat cu sindromul metabolic au un prognostic nefast. Scopul acestei lucrări este de a analiza asocierea dintre FGNA și evoluția COVID-19, precum și posibilele implicaţii terapeutice, axându-se pe cele mai recente actualizări și cercetări din domeniu.

Keywords: COVID-19, NAFLD, MAFLD, liver, diabetes, metabolic syndrome

\section{Introduction}

Coronavirus disease (COVID-19) is an infectious condition caused by the severe acute respiratory syndrome coronavirus 2 (SARS-COV-2), its origins being associated with the City of Wuhan, China [32]. Due to its rapid transmission and progressivity, COVID-19 reached pandemic proportions, leading to the scientific efforts meant to identify risk factors for developing severe illness and death. Factors for poor prognosis have been identified in previous studies around the world and are represented by non-Caucasian racial group, older individuals, male gender [15] and the presence of comorbidities, particularly metabolic conditions, such as diabetes mellitus, obesity, and conditions involving liver function. In a study conducted in the United States during March 2020 on a cohort of 1482 patients hospitalized with COVID-19, $48.3 \%$ were obese, $34.6 \%$ had chronic liver diseases, $28.3 \%$ diabetes mellitus and $27.8 \%$ had cardiovascular diseases [12]. A recent meta-analysis from China on a cohort of 46,248 patients has shown that the most common comorbidity found in people infected with COVID-19 was hypertension $(17 \pm 7.95 \%$ confidence interval $[\mathrm{CI}] 14-22 \%)$, followed by diabetes $(8 \pm 6$, $95 \%$ CI $6-11 \%)$, cardiovascular diseases $(5 \pm 4.95 \%$ CI $4-7 \%$ ) and obesity [39]. Arthur Simonnet et al. concluded in a study which documented the connection between obesity and the risk factors for early invasive mechanical ventilation in patients with COVID-19 that disease severity increased with BMI, individuals with $\mathrm{BMI}>35 \mathrm{~kg} / \mathrm{m}^{2}$ having a 7 -fold higher risk than those with BMI $<25 \mathrm{~kg} / \mathrm{m}^{2}$ [33].

Hence, the metabolic syndrome, which is defined by a cluster of conditions that include dyslipidaemia, raised blood pressure, abdominal obesity and insulin resistance, can be considered a risk factor for severe COVID-19 [28]. Moreover, this constellation of metabolic derangements is linked to a higher risk of 
type II diabetes mellitus (T2DM) and coronary heart disease.

The majority of patients with these comorbidities that are also suffering from COVID-19 developed liver damage, more frequently in severe infections than in mild ones [11]. Recent reports found that the incidence of hepatic injury in COVID-19 ranged between 14.8\% and $53 \%$. Liver damage was indicated, in particular, by increased alanine aminotransferase (ALT)/aspartate aminotransferase (AST), low albumin levels, slightly elevated bilirubin and increased gamma-glutamyl transferase (GGT) that were mostly present in severe patients $[10,15,42]$. In a study designed to determine the clinical characteristics of non-survivors with COVID-19, the incidence of liver injury was of $78 \%$ [42], particularly in those presenting with non-alcoholic fatty liver disease (NAFLD) and high BMI [19]. Therefore, NAFLD, which is known as the hepatic consequence of the metabolic disorders, is included as a risk factor for severe SARS-COV-2 infection. NAFLD has a global prevalence of approximately $25 \%$ and is defined as an excessive fat accumulation in the liver and the exclusion of other causes of hepatic disease. The incidence of NAFLD is increasing with the alarming rise of obesity and high prevalence of T2DM, metabolic syndrome, and is now a leading cause of chronic liver disease [41]. Emerging observations highlight the important role of NAFLD and T2DM in COVID-19 severity [19]. Researches on the link between these conditions are still scarce and while the global pandemic of COVID19 evolves, the clinical and economic burden of NAFLD is likely to increase.

This review will summarize the current state of knowledge regarding the relationship between NAFLD and COVID-19 and the treatment considerations in these patients.

We have systematically searched Google Scholar and Pub Med databases until July $1^{\text {st }} 2020$ using the following keywords: COVID-19, NAFLD, MAFLD, liver, diabetes and metabolic syndrome.

\section{SARS-CoV-2 infection and hepatic function}

Recent studies on COVID-19 have shown that SARSCoV-2 infection causes a systemic multi-visceral disease, causing major damage, including death [17]. Apart from patients with pre-existing advanced chronic liver diseases who developed severe forms of COVID19 due to the "cytokine storm", in most of the cases, liver seems to be only mildly affected and liver-related mortality is not casually expected [10].

Liver involvement is likely multifactorial due to dysregulated immune response, sepsis, drug-induced hepatotoxicity or direct viral cytopathogenic effect. Single-cell genomics studies of healthy hepatic tissues have shown that the SARS-CoV-2 receptor, represented by the angiotensin-converting enzyme 2 (ACE2), has a higher expression in cholangiocytes, with a 20 -fold lower expression in hepatocytes [6, 27], which might explain why viral hepatitis is not a frequent finding in COVID-19 infection.

In the largest and most comprehensive study that describes the liver laboratory test results in patients with COVID-19, the findings are evocative. Out of 417 patients, $76.3 \%$ had elevated liver function tests results and $21.5 \%$ had liver injury during hospital stay. More than $90 \%$ with elevated liver enzymes were mild $(<2 \times$ ULN), and about $24 \%$ developed more than $>3 \times$ ULN during hospitalization. Regarding the patterns, $20.75 \%$ were hepatocellular injury, $29.25 \%$ were cholestatic and $43.4 \%$ were mixed type [4].

NAFLD in T2DM patients and COVID-19

NAFLD includes several clinic-pathologic elements: non-alcoholic fatty liver (NAFL), non-alcoholic steatohepatitis (NASH), fibrosis and cirrhosis. Characterized by more than $5 \%$ of hepatocellular fat infiltration without other potential causes of liver injury, NAFLD regularly coexists with metabolic disorders like T2DM, cardiovascular disease and obesity. A global report on diabetes has shown that its prevalence is estimated at around $8.5 \%$ [36]. From among the T2DM patients, $70-80 \%$ have NAFLD [34]. They usually coexist, the presence of NAFLD increasing the incidence of T2DM and its complications, while T2DM accelerates the progression of NAFLD to more severe forms of liver diseases [1].

Since the prevalence rate of NAFLD increases with higher BMI [29], obesity is considered to play a pathogenic role in the association with insulin resistance, diabetes and dyslipidaemia. Apart from the clear causal relationship of obesity to the premature development of cardiovascular diseases, there is also a metabolic concern. In individuals with T2DM, excess fat tissue leads to additional reduced $\beta$-cell function and insulin resistance, one of the multiple hits determining NAFLD and progression to NASH. Moreover, obesity was demonstrated to be a major risk factor for poor outcomes in SARS-CoV-2 infection. The OpenSafely study (17,425,445 subjects, 5683 COVID-19 deaths) has shown a dose-response association between excess weight and the disease severity of SARS-CoV-2 infection, from a $27 \%$ higher risk in the first class of obesity (BMI 30 - 34.9; hazard ratio $1.27,1.18$ to 1.36 ) to more than double the risk in the third class (BMI > $40 ; 2.27,1.99$ to 2.58 ) [37]. Smaller global reports confirmed these findings [31, 33, 39]. Multiple common metabolic and inflammatory pathways link obesity, T2DM and NAFLD to SARS-CoV-2 infection; obesity causes insulin resistance and hyperglycaemia, whereas SARS-CoV-2 may cause elevated serum glucose as well (however, the underlying mechanisms are yet to be elucidated) [24]. Moreover, obesity and NASH represent a state of chronic low-grade systemic inflammation, that seems to cause dysfunctional immune responses, as it has been shown in the case 
of the influenza virus [14], leading to a greater risk of COVID-19 cytokine storm.

In a study conducted on 202 patients confirmed with SARS-CoV-2 infection, information regarding NAFLD status was gathered. Liver injury was detected in 50\% of the patients upon admission and in $75.2 \%$ during hospitalization. Of all the patients, $19 \%$ had progressive forms of the disease and $80.7 \%$ remained stable. Patients with progressive forms had a higher BMI (OR 1.3; 95\% CI 1.0 - 1.8), T2DM (OR 6.3; 95\% CI 2.3 - 18.8) and NAFLD (OR 6.4; 95\% CI 1.5 - 31.2). NAFLD was linked to a higher probability of developing elevated liver function tests from admission to discharge (70\% [53/76] vs. 11.1\% [14/126]; $\mathrm{p}<0.0001)$, longer viral shredding time $(17.5 \pm 5.2$ days $v s .12 .1 \pm 4.4$ days $\mathrm{p}<0.0001)$ and an increased risk for severe disease (6.6\% [5/126] vs. 44.7\% [34/76] p < 0.0001) [19]. Autopsy liver biopsy specimens in one patient with NAFLD showed diffuse micro-vesicular steatosis with lobular and portal inflammation and hyper-activated CD4 and CD8 T cells, suggesting that hepatic damage is immune mediated and implying the over-activation of T cells with a high cytotoxicity of CD8 subtypes [38]. Liver inflammation due to inflammatory cytokines that are discharged by the adipose tissue becomes clear, with an inflammatory status characterized by higher circulating interleukin 6 (IL-6) levels. SARS-CoV-2 infection leads to a malfunction of immune response in the adipose tissue of the liver associated with dysregulation of cytokine profiles. A "cytokine storm" is activated in this context, with potent inflammatory cytokines such as tumour necrosis factor $\alpha$ (TNF $-\alpha)$, interleukin 1 (IL-1) and IL-6 [22]. Liver adipose tissue is one of the main sources of IL- 6 that is a strong predictor of mortality in this situation [31]. Associated to these mechanisms are metabolic dysfunctions, including insulin resistance with fatty acids oxidation disorders [35].

A genomic analysis on the influence of MAFLD (metabolic associated fatty liver disease - a proposed nomenclature for fatty liver associated with metabolic derangements) [9] on hepatic gene expression profiles of the proteins involved in SARS-CoV-2 infection, showed that none of the genes that are necessary for COVID-19 were expressed neither in the control group or in patients with NAFL or with NASH. The study concluded that there is no link between MAFLD and liver expression of genes involved in SARS-CoV-2 infection. This strengthens the hypothesis that the cytokine storm is the mechanism that underlies liver damage and not the direct cytopathic effects of the virus [3].

One multi-centre study (COVID-MAFLD-CHESS) connects the effects of MAFLD to COVID-19 poor outcomes [44]. In patients below the age of 60, a 2 fold higher risk of severe SARS-CoV-2 infection was found in those with MAFLD compared to healthy subjects. Moreover, MAFLD was not linked to poor prognosis in patients with advanced ages $(\mathrm{p}<0.05)$. The underlying mechanism is unknown. It is suggested that the liver damage and immunological changes induced by MAFLD leads to the "cytokine storm" in patients with COVID-19 at earlier ages [25]. In older subjects, other associated comorbidities are more frequent and any link to MAFLD might be hidden by these chronic conditions [15].

Treatment considerations

COVID-19 is triggered by the binding of SARS-CoV2 to the ACE2 receptor that is mostly expressed in the upper and lower respiratory system, kidney, heart and liver. Recent data suggests that renin-angiotensin system (RAS) inhibitors can increase the ACE2 levels [43]. However, studies on patients that were on longterm treatment with RAS inhibitors have shown that the level of ACE2 receptors was increased in the intestine, but not in the lungs, liver or heart [8].

In individuals with NAFLD and T2DM, there is a direct link to COVID-19 explained by the higher level of ACE2 receptors on the pancreatic islets, with decreased insulin secretion. Hyperglycaemia, a state of metabolic inflammation that inhibits the immune system, leads to a more severe form of COVID-19 and poor prognosis [7]. This supports the fact that SARS-CoV-2 acutely injures the pancreatic islets and can cause acute insulin dependent diabetes mellitus [40].

Preventing measures for SARS-CoV-2 infection are mandatory for these patients. As new evidence emerges, patients with NAFLD and metabolic disorders such as T2DM, obesity and hypertension, exhibit a higher risk for severe SARS-CoV-2 infection and should be admitted for inpatient care on COVID-19 wards or hospitals. Although there is no specific antiviral drug for COVID-19, a few drugs have been tested over the last months [16]. Patients with chronic liver diseases that are NAFLD-related are at a high of drug toxicity (i.e. patients with Child B/C cirrhosis) and must be closely monitored. Individuals with decompensated cirrhosis, treatment of associated complications should be continued. It is also important to highlight the prevention of acetaminophen overdosing (2 - 3/day is considered safe), since acetaminophen is preferable for treating COVID-19-associated fever as compared to NSAID (nonsteroidal anti-inflammatory drugs), particularly in older patients who are more likely to already have a compromised kidney function [30]. Since T2DM is one of the most common comorbidities of COVID-19, with patients who developed SIRS and furthermore, acute respiratory distress syndrome (ARDS), metabolic control is essential. There are multiple therapies to treat these patients and maintain glycaemic control. Antidiabetic agents known as glucagon-like peptide-1 (GLP-1) exert significant antiinflammatory effects, particularly in inflammationinduced acute lung injury, as shown in murine models [20]. These beneficial effects, which include inhibition of the main inflammatory cytokines and chemokines, 
make GLP-1 therapeutic agents potential drugs for the treatment of SARS-CoV-2 infection in patients with or without T2DM. However, further clinical and experimental researches on humans are needed to demonstrate the correlation between these drugs and COVID-19. Dipeptidyl peptidase-IV inhibitors (DPP-IV) seem to play an important role in reducing macrophage infiltration by modulating M1/M1 macrophage polarization in diabetic mice [18], suggesting a promising target to modify the disease progression and to reduce the complications that T2DM may add to SARS-CoV-2 infection.

The insulin-sensitizing drug, metformin, does not have an important benefit in improving histological and clinical features in NASH or fibrosis and is considered to have a weak effect on liver fat by recent guidelines [13]. Accumulating evidence indicates that pioglitazone, an actual treatment for NASH recommended by the current guidelines in Europe and United States [13], decreases death rate from sepsis and acute respiratory distress syndrome in COVID-19 by reducing the levels of pro-inflammatory cytokine in adipose liver and omental tissue [23]. Mechanisms are still under study. Peroxisome proliferator-activated receptor-gamma (PPAR- $\gamma$ ), a nuclear hormone receptor family, is expressed in T cells, dendritic cells and macrophages. It has been shown that PPAR- $\gamma$ activation by its ligand, pioglitazone, attenuates the antigen uptake and dendritic T-cell interaction at the initiation of immune response. A low dose of pioglitazone, $15 \mathrm{mg}$ per day, suppresses the inflammatory effects of TNF- $\alpha$ and IL-6 and seems to be preferred as a treatment option to induce anti-inflammatory effects for COVID19 patients [5]. Taken together, pioglitazone, which is not a well-accepted treatment for T2DM because of its many side effects, can be a new therapeutic outlook in the treatment of COVID-19 by improving the hepatic damage caused by SARS-CoV-2 infection [26]. Moreover, recent diabetes management guidelines suggest that an SGLT-2 inhibitor (empagliflozin) may lower hepatic fat content in patients with T2DM and can be used as the first-line treatment in NAFLD [21]. Since obesity has been found to play a key role in the severity of SARS-CoV-2 infection, therapeutic interventions are mandatory. People should be encouraged to improve their lifestyle (e.g., exercise more, adopt low-calorie diets, use proven weight loss drugs) to reduce the risk of developing severe COVID-19. Moreover, stronger messages should be adopted to encourage people to eat healthier and make sustainable changes. In the UK, the "Better Health" campaign led by Public Health England was launched to help people embrace a healthier lifestyle and lose weight.

\section{Conclusions}

Similarly to other studies and reports, this review paper assesses the effects of NAFLD for severe courses of
COVID-19, longer viral shredding time and a higher frequency of liver injury (increased liver enzymes) from admission to discharge. Autopsy liver biopsy specimens in one patient with NAFLD-related liver diseases showed diffuse micro-vesicular steatosis with lobular and portal inflammation and hyper-activated $\mathrm{T}$ cells, suggesting that hepatic damage is immune mediated. In addition, recent studies suggest that chronically elevated insulin levels in MAFLD are linked to reduced lung function, even in non-diabetic patients [2].

To put that into context, considering the worldwide prevalence of NAFLD, 25\% of the total population carries a higher risk for COVID-19. This stands as proof for the importance of the medical care, prophylaxis, monitoring and treatment for this risk group. Overall, the best approach for these patients during the COVID19 pandemic is to establish a good metabolic control. Even so, further studies validated by large cohorts of patients to acknowledge the role of NAFLD in COVID-19 are needed.

Finally, the association between NAFLD, T2DM and SARS-CoV-2 infection raises special challenges. These findings highlight the urgent need for a multidisciplinary team-based approach, as this is an essential approach to lower the risk of severe disease as much as possible. Careful evaluation and management of all the factors that increase the overall mortality in COVID-19 patients and individualized, patient-centred treatment might actually be the only way to overcome this pandemic.

\section{Conflict of interest}

The authors declare no conflict of interest.

\section{References}

1. Adams LA, Waters OR, Knuiman MW, Elliott RR, NAFLD as a risk factor for the development of diabetes and the metabolic syndrome: An eleven-year followup study. Am J Gastroenterol., 2009; 104(4): 861-867.

2. Baffi CW, Wood L, Winnica D, Strollo PJ, Gladwin MT, Que LG, Holguin F, Metabolic Syndrome and the Lung. Chest, 2016; 149(6): 1525-1534.

3. Biquard L, Valla D, Rautou PE. No evidence for an increased liver uptake of SARS-CoV-2 in metabolicassociated fatty liver disease. J Hepatol., 2020; 73(3): 717-718.

4. Cai Q, Huang D, Yu H, Zhu Z, Xia Z, Su Y, Li Z, Zhou G, Gou J, Qu J, Sun Y, Liu Y, He Q, Chen J, Liu L, Xu L, COVID-19: Abnormal liver function tests. J Hepatol., 2020; 73(3): 566-574.

5. Carboni E, Carta AR, Carboni E, Can pioglitazone be potentially useful therapeutically in treating patients with COVID-19?. Med Hypotheses, 2020; 140: 109776: 1-4.

6. Catrinoiu D, Ceriello A, Rizzo M, Serafinceanu C, Montano N, Pantea Stoian A, Udeanu DI, Jinga V, Iorgulescu G, Dumitrescu IB, Diabetes and reninangiotensin-aldosterone system: implications for COVID- 
19 patients with diabetes treatment management. Farmacia, 2020; 68(3): 377-383.

7. Critchley JA, Carey IM, Harris T, DeWilde S, Hosking FJ, Cook DG, Glycemic control and risk of infections among people with type 1 or type 2 diabetes in a large primary care cohort study. Diabetes Care, 2018; 41(10): 2127-2135.

8. Epelman S, Shrestha K, Troughton RW, Francis GS, Sen S, Klein AL, Soluble Angiotensin-Converting Enzyme 2 in Human Heart Failure: Relation With Myocardial Function and Clinical Outcomes. J Card Fail, 2009; 15(7): 565-571.

9. Eslam M, Sanyal AJ, George J, Sanyal A, Tiribelli C, Kleiner DE, Brunt E, Bugianesi E, Yki-Järvinen H, Grønbæk H, Cortez-Pinto H, Fan J, Valenti L, RomeroGomez M, Rinella M, Arrese M, Bedossa P, Newsome PN, Anstee QM, Jalan R, Bataller R, Loomba R, Sarin SK, Harrison S, Kawaguchi T, Wong VWS, Ratziu V, Yilmaz Y, Younossi Z, MAFLD: A Consensus-Driven Proposed Nomenclature for Metabolic Associated Fatty Liver Disease. Gastroenterol., 2020; 158(7): 1999-2014.

10. Fan Z, Chen L, Li J, Cheng X, Yang J, Tian C, Zhang Y, Huang S, Liu Z, Cheng J. Clinical Features of COVID-19-Related Liver Functional Abnormality. Clin Gastroenterol Hepatol., (2020); 18(7): 1561-1566.

11. Fan Z, Chen L, Li J, Tian C, Zhang Y, Huang S, Liu Z, Cheng J, Clinical Features of COVID-19 Related Liver Damage. SSRN Electron J., 2020; 18(7): 15611566.

12. Garg S, Kim L, Whitaker M, O'Halloran A, Cummings C, Holstein R, Prill M, Chai SJ, Kirley PD, Alden NB, Kawasaki B, Yousey-Hindes K, Niccolai L, Anderson EJ, Openo KP, Weigel A, Monroe ML, Ryan P, Kim S, Como-Sabetti K, Lynfield R, Sosin D, Torres S, Muse A, Bennett NM, Billing L, Sutton M, West N, Schaffner W, Keipp Talbot H, Aquino C, George A, Budd A, Brammer L, Langley G, Hall AJ, Fry A, Hospitalization rates and characteristics of patients hospitalized with laboratory-confirmed coronavirus disease 2019 - COVID-net, 14 states, March 1-30, 2020. Morb Mortal Wkly Rep., 2020; 69(15): 458-464.

13. Gastaldelli A, Cusi K, From NASH to diabetes and from diabetes to NASH: Mechanisms and treatment options. JHEP Rep., 2019; 1(4): 312-328.

14. Green WD, Beck MA, Obesity impairs the adaptive immune response to influenza virus. Ann Am Thorac Soc., 2017; 14(Supplement_5): S406-S409.

15. Guan W, Ni Z, Hu Y, Liang W, Ou C, He J, Liu L, Shan H, Lei C, Hui DSC, Du B, Li L, Zeng G, Yuen KY, Chen R, Tang C, Wang T, Chen P, Xiang J, Li S, Wang JL, Liang Z, Peng Y, Wei L, Liu Y, Hu YH, Peng P, Wang JM, Liu J, Chen Z, Li G, Zheng Z, Qiu S, Luo J, Ye C, Zhu S, Clinical characteristics of coronavirus disease 2019 in China. $N$ Engl J Med., 2020; 382: 1708-1720.

16. Harrison $\mathrm{C}$, Coronavirus puts drug repurposing on the fast track. Nat Biotechnol., 2020; 38(4): 379-381.

17. Huang $\mathrm{C}$, Wang $\mathrm{Y}, \mathrm{Li} \mathrm{X}$, Ren $\mathrm{L}$, Zhao J, Hu Y, Zhang L, Fan G, Xu J, Gu X, Cheng Z, Yu T, Xia J, Wei Y, Wu W, Xie X, Yin W, Li H, Liu M, Xiao Y, Gao H, Guo L, Xie J, Wang G, Jiang R, Gao Z, Jin Q, Wang J, Cao B, Clinical features of patients infected with 2019 novel coronavirus in Wuhan, China. Lancet, 2020; 395(10223): 497-506.
18. Iacobellis G, COVID-19 and diabetes: Can DPP4 inhibition play a role?. Diab Res Clin Pract., 2020; 162: 108125: 1-2.

19. Ji D, Qin E, Xu J, Zhang D, Cheng G, Wang Y, Lau $\mathrm{G}$, Non-alcoholic fatty liver diseases in patients with COVID-19: A retrospective study. J Hepatol., 2020; 73(2): 451-453.

20. Jin T, Liu M, Letter to the editor: Comment on GLP1-based drugs and COVID-19 treatment. Acta Pharm $\operatorname{Sin} B, 2020 ; 10(7)$ : 1249-1250.

21. Kahl S, Gancheva S, Straßburger K, Herder C, Machann J, Katsuyama H, Kabisch S, Henkel E, Kopf S, Lagerpusch M, Kantartzis K, Kupriyanova Y, Markgraf D, Van Gemert T, Knebel B, Wolkersdorfer MF, Kuss O, Hwang JH, Bornstein SR, Kasperk C, Stefan N, Pfeiffer A, Birkenfeld AL, Roden M, Empagliflozin effectively lowers liver fat content in well-controlled type 2 diabetes: A randomized, double-blind, phase 4, placebo-controlled trial. Diab Care, 2020; 43(2): 298-305.

22. Kern L, Mittenbühler MJ, Vesting AJ, Ostermann AL, Wunderlich CM, Wunderlich FT, Obesity-induced TNF $\alpha$ and IL- 6 signaling: The missing link between obesity and inflammation- driven liver and colorectal cancers. Cancers (Basel), 2019; 11(1): 24: 1-21.

23. Kutsukake M, Matsutani T, Tamura K, Matsuda A, Kobayashi M, Tachikawa E, Uchida E. Pioglitazone attenuates lung injury by modulating adipose inflammation. J Surg Res., 2014; 189(2): 295-303.

24. Michalakis K, Ilias I, SARS-CoV-2 infection and obesity: Common inflammatory and metabolic aspects. Diab Metab Syndr Clin Res Rev., 2020; 14(4): 469-471.

25. Narayanan S, Surette FA, Hahn YS, The immune landscape in nonalcoholic steatohepatitis. Immune Netw., 2016; 16(3): 147-158.

26. Penlioglou T, Papachristou S, Papanas N, COVID-19 and Diabetes Mellitus: May Old Anti-diabetic Agents Become the New Philosopher's Stone?. Diab Ther., 2020; 11(6): 1195-1197.

27. Qi F, Qian S, Zhang S, Zhang Z, Single cell RNA sequencing of 13 human tissues identify cell types and receptors of human coronaviruses. Biochem Biophys Res Commun., 2020; 526(1): 135-140.

28. Rochlani Y, Pothineni NV, Kovelamudi S, Mehta JL, Metabolic syndrome: Pathophysiology, management, and modulation by natural compounds. Ther $A d v$ Cardiovasc Dis., 2017; 11(8): 215-225.

29. Ruhl CE, Everharty JE, Determinants of the association of overweight with elevated serum alanine aminotransferase activity in the United States. Gastroenterol., 2003; 124(1): 71-79.

30. Russell B, Moss C, Rigg A, Van Hemelrijck M, COVID19 and treatment with NSAIDs and corticosteroids: Should we be limiting their use in the clinical setting?. Ecancermedicalscience, 2020; 14: 1023: 1-3.

31. Ryan PMD, Caplice NM, Is Adipose Tissue a Reservoir for Viral Spread, Immune Activation, and Cytokine Amplification in Coronavirus Disease 2019?. Obesity, 2020; 28(7): 1191-1194.

32. Shereen MA, Khan S, Kazmi A, Bashir N, Siddique R, COVID-19 infection: Origin, transmission, and characteristics of human coronaviruses. $J$ Adv Res., 2020; 24: 91-98. 
33. Simonnet A, Chetboun M, Poissy J, Raverdy V, Noulette J, Duhamel A, Labreuche J, Mathieu D, Pattou F, Jourdain M, Caizzo R, Caplan M, Cousin N, Duburcq T, Durand A, El kalioubie A, Favory R, Garcia B, Girardie P, Goutay J, Houard M, Jaillette E, Kostuj N, Ledoux G, Mathieu D, Moreau AS, Niles C, Nseir S, Onimus T, Parmentier E, Préau S, Robriquet L, Rouze A, Six S, Verkindt H, High Prevalence of Obesity in Severe Acute Respiratory Syndrome Coronavirus-2 (SARS-CoV-2) Requiring Invasive Mechanical Ventilation. Obesity, 2020; 28(7): 1195-1199.

34. Targher G, Non-alcoholic fatty liver disease, the metabolic syndrome and the risk of cardiovascular disease: The plot thickens. Diabet Med., 2007; 24(1): 1-6.

35. Trim W, Turner JE, Thompson D, Parallels in immunometabolic adipose tissue dysfunction with ageing and obesity. Front Immunol., 2018; 9: 169: 1-22.

36. World Health Organization. Global report on diabetes. WHO Press, 1211 Geneva 27, Switzerland, 2016; 20-21.

37. Williamson EJ, Walker AJ, Bhaskaran K, Bacon S, Bates C, Morton CE, Curtis HJ, Mehrkar A, Evans D, Inglesby P, Cockburn J, McDonald HI, MacKenna B, Tomlinson L, Douglas IJ, Rentsch CT, Mathur R, Wong AYS, Grieve R, Harrison D, Forbes H, Schultze A, Croker R, Parry J, Hester F, Harper S, Perera R, Evans SJW, Smeeth L, Goldacre B, OpenSAFELY: factors associated with COVID-19 death in 17 million patients. Nature, 2020; 584(7821): 430-436.
38. Xu Z, Shi L, Wang Y, Zhang J, Huang L, Zhang C, Liu S, Zhao P, Liu H, Zhu L, Tai Y, Bai C, Gao T, Song J, Xia P, Dong J, Zhao J, Pathological findings of COVID-19 associated with acute respiratory distress syndrome. Lancet Respir Med., 2020; 8(4): 420-422.

39. Yang J, Zheng Y, Gou X, Pu K, Chen Z, Guo Q, Ji R, Wang H, Wang Y, Zhou Y, 2020 Prevalence of comorbidities and its effects in coronavirus disease patients: A systematic review and meta-analysis. Int $J$ Infect Dis., 2019; 94: 91-95.

40. Yang JK, Lin SS, Ji XJ, Guo LM, Binding of SARS coronavirus to its receptor damages islets and causes acute diabetes. Acta Diabetol., 2010; 47(3): 193-199.

41. Younossi ZM, Koenig AB, Abdelatif D, Fazel Y, Henry L, Global epidemiology of nonalcoholic fatty liver disease - Meta-analytic assessment of prevalence, incidence, and outcomes. Hepatology, 2016; 64(1): 73-84.

42. Zhang C, Shi L, Wang FS, Liver injury in COVID-19: management and challenges. Lancet Gastroenterol Hepatol., 2020; 5(5): 428-430.

43. Zheng YY, Ma YT, Zhang JY, Xie X, COVID-19 and the cardiovascular system. Nat Rev Cardiol., 2020; 17(5): 259-260.

44. Zhou YJ, Zheng KI, Wang XB, Yan HD, Sun QF, Pan KH, Wang TY, Ma HL, Chen YP, George J, Zheng $\mathrm{MH}$, Younger patients with MAFLD are at increased risk of severe COVID-19 illness: A multicenter preliminary analysis. J Hepatol., 2020; 73(3): 719-721. 